$31: 570$

シンポジウム

<総＼cjkstart説 $>$

\title{
CKD 患者の脳卒中一その実態を中心に一
}

\author{
寺脇 博之 ${ }^{1)}$ 中山 昌明 ${ }^{2}$
}

Key words : 慢性腎臓病, 脳卒中, コホート研究, 透析, 透析導入前

(脳卒中 $31: 570-574,2009$ )

\section{はじめに}

慢性腎臓病 (chronic kidney disease : CKD) の定義 は, (1)腎機能低下 $\left(\mathrm{GFR}<60 \mathrm{~mL} / \mathrm{min} / 1.73 \mathrm{~m}^{2}\right)$, (2)持 続的腎障害(蛋白尿, 血尿, 腎の形態異常)の少なくと も一方が 3 カ月以上続く状態である ${ }^{1)}$. 本邦におい て, 腎機能低下を示すものの割合は成人人口の約 2 割 と推計されている゙ ことょり, CKD は本邦の common disease であると言える. 近年の疫学的検討によ り，この CKD が総死亡および心血管疾患の危険因子 である状況が明らかにされている ${ }^{3) \sim 5)}$. また CKD と 脳卒中との関連についても, 徐々に知見が集積しつつ ある.

一方 CKD の中でも，すでに維持透析を施行されて いる末期腎不全患者では, 総死亡 ·心血管疾患とも高 頻度であることが従来から認識されている ${ }^{6)}$. そして 脳卒中に関しても, 本邦の透析患者の死因のうち 3 位 を占めること7)よりその関連性は明白である.

$\mathrm{CKD}$ の存在がなぜ心血管疾患や脳卒中などの血管 合併症を高頻度に惹起するのか, その詳細は完全には 明らかにされていないが, 恒常性維持能の破綻を基礎

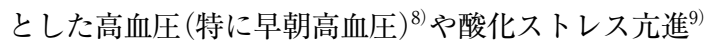
の関与が指摘されており, 最近では, カテコラミン代 謝酵素である renalase の腎における産生低下 ${ }^{10)}$, 脳 と腎臓に共通する strain vessel の傷害による機序 ${ }^{11}$ が 提唱されている.

本稿では，このような透析導入前および導入後

\footnotetext{
${ }^{1)}$ 東京慈恵会医科大学腎臓・高血圧内科

${ }^{2}$ 東北大学大学院医学系研究科腎不全対策研究講座

(2009 年 9 月 6 日受付, 2009 年 9 月 9 日受理)
}

CKD 患者と脳卒中との関連について，その実態を中 心に概説する.

\section{透析導入前 CKD と脳卒中}

透析導入前 $\mathrm{CKD}$ と総死亡・心血管疾患との関連性 が広く認識されるに至った噮矢は, 2004 年の Go らに よる報告である ${ }^{3)}$. 1,120,295 名の米国カリフォルニア 州一般住民を平均 2.84 年追跡したこの報告におい て, 腎機能低下は総死亡・心血管疾患の合併および入 院加療の独立した危険因子であることが示された．さ らに本邦のコホート研究においても同様の結果が報告 されるに至り ${ }^{4) 5)}$, 欧米同様に本邦でも一般住民にお ける CKD と総死亡・心血管疾患との関連性が確認さ れた次第である。

一方, 透析導入前 $\mathrm{CKD}$ と脳卒中との関連について は，総死亡・心血管疾患との関連ほどには現状が 明 らかにされていないが，近年に至り徐々に知見が集積 しつつある。

海外からの報告として, Koren-Morag らは心疾患 合併例を対象とした観察研究において, GFR $<$ $60 \mathrm{~mL} / \mathrm{min} / 1.73 \mathrm{~m}^{2}$ の集団において脳卒中を発症しゃ すいトレンドが認められたと報告している ${ }^{12)}$. また Abramson らは, 貧血と腎機能低下 $(\mathrm{GFR}<60 \mathrm{~mL} /$ $\mathrm{min} / 1.73 \mathrm{~m}^{2}$ )を併存する集団において脳卒中の発症リ スクが高かったと報告している ${ }^{13)}$.

本邦からもいくつかの重要な報告がなされてい る. Irie らは茨城県の死亡診断書に基づいた検討結果 として, $\mathrm{GFR}<60 \mathrm{~mL} / \mathrm{min} / 1.73 \mathrm{~m}^{2}$ の集団においては 性別を問わず脳卒中による死亡相対危険度が約 2 倍で あったと報告している ${ }^{14)}$. Ninomiya らは久山町研究 からの知見として，腎機能低值の女性において脳梗塞 


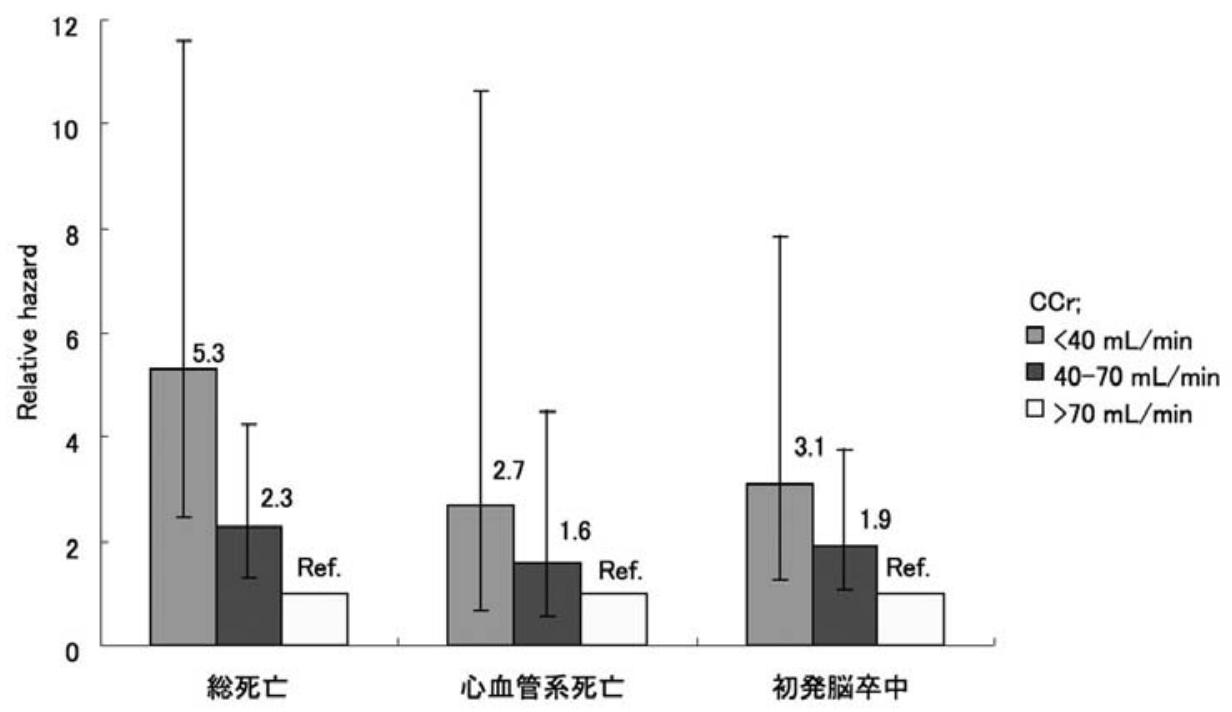

図 1 腎機能低值が総死亡・心血管系死亡・初発脳卒中に及ぼすリスク

腎機能低值は，総死亡および初発脳卒中の有意な危険因子であった.（文献 5 より作図）

リスクが高いと報告している ${ }^{15)}$. 我々も大迫研究を通 じて，腎機能低值が新規症候性脸卒中発症の危険因子 である状況を確認しており ${ }^{5)}$ ，その詳細を次段で紹介 する.

腎機能(推定クレアチニンクリアランス : CCr) が 明らかな大迫町一般住民 1,977 名 (平均年齢 62.9 歳,

男 : 女 $=731: 1,246)$ を平均 7.76 年追跡し, $\mathrm{CCr}$ と総 死亡・心血管系死亡および新規脳卒中発症との関連に つき検討した，その結果, 総死亡についてはGoらの 報告同様 CCr が低いほど有意に高頻度であることが 示されたが, 心血管系死亡については (Go らの報告 ${ }^{3)}$ と異なり)その傾向はあるものの有意性は示されな かった. 一方, 新規症候性脳卒中の発症についての検 討では, $\mathrm{CCr}$ が $40 \mathrm{~mL} / \mathrm{min}$ 未満である住民集団では $70 \mathrm{~mL} / \mathrm{min}$ 以上の集団と比較して新規症候性脳卒中を 高頻度に発症し, 交絡因子で補正後の比例ハザードは 3.1 倍 (95\%信頼区間：1.24-7.84)であった(図 1). 本検 討から得られた意義は少なくとも2 点ある. 1 点目 は, CKD が日本人に扔いて新規症候性脳卒中の危険 因子であることを初めて明らかにした点, 2 点目 は，CKD が心血管系に与える影響が人種により異な る可能性を示唆した点である.

\section{透析導入後 CKD 患者と脳卒中}

透析導入前 $\mathrm{CKD}$ と脳卒中との関係が明らかにされ はじめたのはごく最近である一方，すでに透析導入に 至った CKD 患者と脳卒中との関係は以前から広く認 識されている. 脳卒中は透析療法の黎明期より一貫し て透析患者における死亡の主因であり続けてきた。し かしながら，透析患者と脳卒中との関連性の推移を経 時的観点から概観すると, 若干の変化を確認すること ができる.

日本透析医学会により行われる全国調查 (2006 年

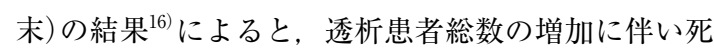
亡者数も増加する一方, 脳卒中による死亡数はここ数 年横ばいであるため, 脳卒中による死亡比率は漸減し ている(図 2).ささらに新規透析導入患者においては, 脳卒中による死亡数・死亡比率とも漸減している(図 3). その一方, 脳卒中(脳梗塞ないし脳出血)の罹患患 者数・有病率はともに増加している(図 4). かかる変 化は透析患者の脳卒中に対する治療成績の向上を意味 するのかもしれないが, 新規透析導入患者における平 均年齢の上昇も大きく影響していると考えられる．実 際, 高齢患者では導入の時点で高頻度に脳梗塞を合併 している(図 5)ことょり, 新規導入患者の平均年齢の 
口 総死亡

口脳卒中死亡

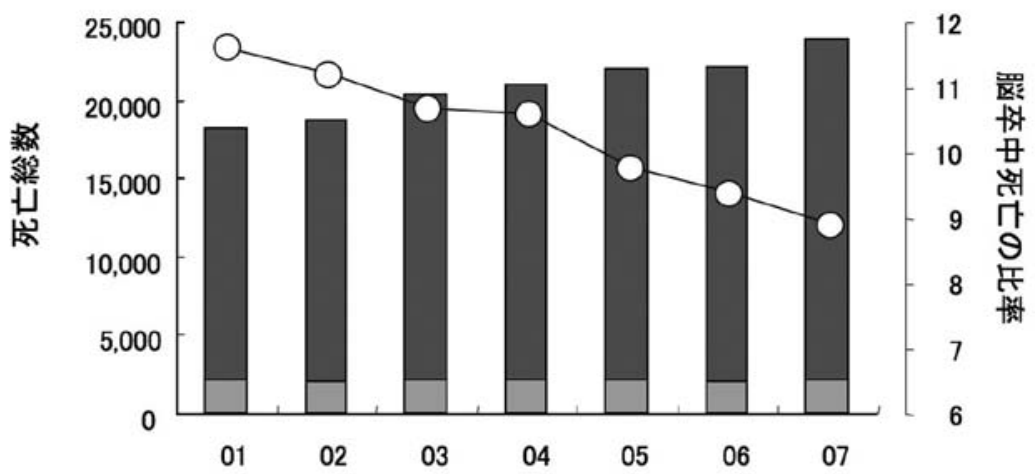

図 2 わが国の透析患者における年間の脳卒中死亡総数

脳卒中死亡数は横ばい状態にあるため, 死亡原因の中で脳卒中が占める割合は漸減傾 向にある。（文献 15 より作図）

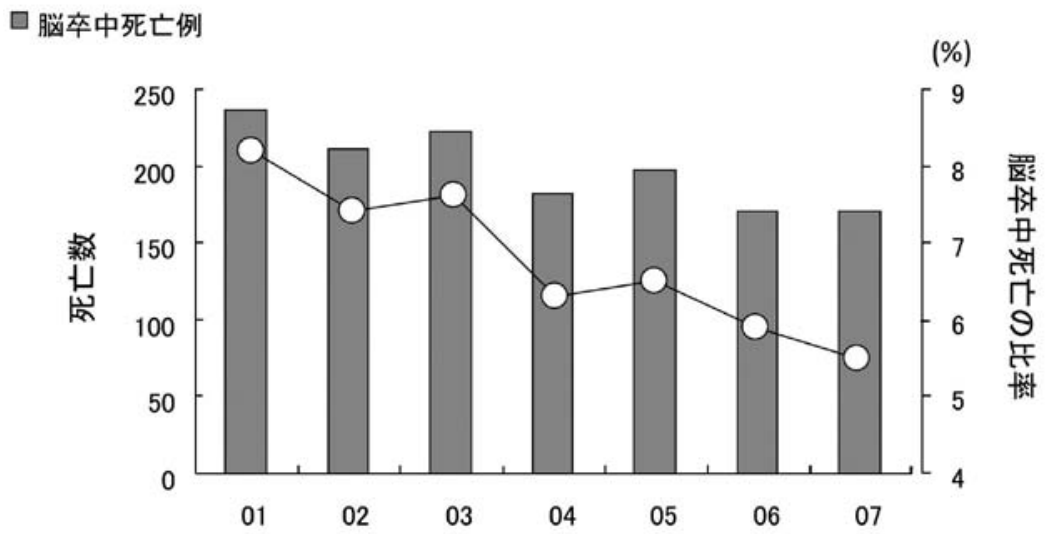

図 3 わが国の新規透析導入患者における脳卒中死亡数

脳卒中死亡数, 脳卒中死亡比率ともに減少している. (文献 15 より作図)

(\%)

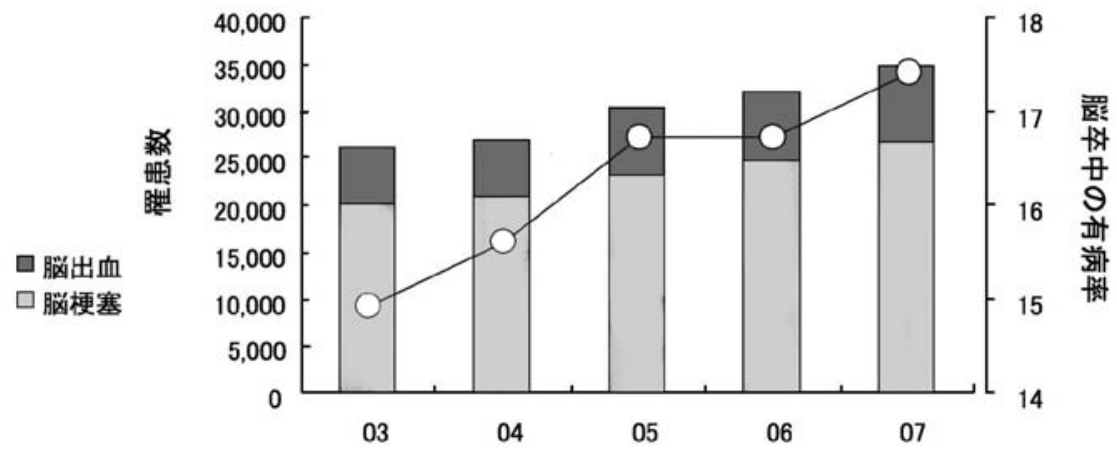

図 4 わが国の透析患者における脳卒中罹患患者数と有病率

脳卒中 (脳梗塞・脳出血)の有病例・有病率ともに増加している. (文献 15 より作図) 


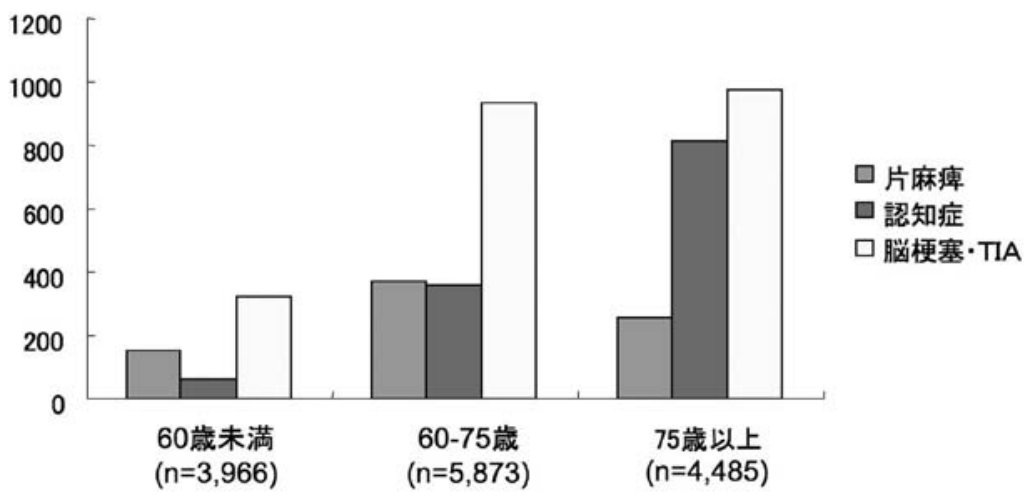

図 52006 年度新規透析導入患者 $(28,353$ 例)のうち, 医療情報が確認できた 14,318 例の合併症 高齢腎不全患者では，透析導入の時点ですでに $20 \%$ 程度が脳梗塞を合併している.（文献 15 より作図）

上昇はただちに脳卒中の罹患数・罹患率増加に直結し うる。

透析患者における脳卒中の「質的」変化を指摘する報 告もある. 福岡赤十字病院の Toyoda らは, 1996 年 を境に脳卒中の主因が脳出血から脳梗塞へと移行した ことを指摘しており, その背景として血圧管理状況の 改善, 画像診断能力の向上, エリスロポエチン製剂の 投与, 高齢者や糖尿病患者の増加の関与を推察してい る. また彼らは, 脳梗塞の好発部位が脳底動脈支配領 域であると指摘しており，そのことへの糖尿病の関連 を推察している17).

\section{おわりに}

透析導入前および導入後 $\mathrm{CKD}$ と脳卒中との関連に ついて，最近の知見を中心に紹介した，CKDの存在 は脳卒中の発症に関わる危険因子であり，脳卒中回避 の観点から今後 CKD 患者に対する適切な介入のあり かたが議論されるべきであろう。

\section{参考文献}

1) National Kidney Foundation: K/DOQI clinical practice guidelines for chronic kidney disease: evaluation, classification, and stratification. Am J Kidney Dis 39 (Suppl): S1-S246, 2002

2) Imai E, Horio M, Iseki K, et al: Prevalence of chronic kidney disease (CKD) in the Japanese general population predicted by the MDRD equation modified by a Japanese coefficient. Clin Exp Nephrol 11: 156-163, 2007

3) Go AS, Chertow GM, Fan D, et al: Chronic kidney disease and the risks of death, cardiovascular events, and hospitalization. N Engl J Med 351: 1296-1305, 2004

4) Ninomiya T, Kiyohara $Y$, Kubo M, et al: Chronic kidney disease and cardiovascular disease in a general Japanese population: The Hisayama study. Kidney Int 68: 228-236, 2005

5) Nakayama M, Metoki H, Terawaki H, et al: Kidney dysfunction as a risk factor for first symptomatic stroke events in a general Japanese population-the Ohasama study. Nephrol Dial Transplant 22: 1910-1915, 2007

6) Foley RN, Parfrey PS, Sarnak MJ: Clinical epidemiology of cardiovascular disease in chronic renal disease. Am J Kidney Dis 32: S112-119, 1998

7）中井 滋, 政金生人, 重松 隆ら：わが国の慢性 透析療法の現況 (2007 年 12 月 31 日現在)。透析会 誌 42: 1-45, 2009

8) Terawaki H, Metoki H, Nakayama M, et al: Masked hypertension determined by self-measured blood pressure at home and chronic kidney disease in the Japanese general population: The Ohasama study. Hypertens Res 31: 2129-2135, 2008

9) Terawaki H, Yoshimura K, Hasegawa T, et al: Oxidative stress is enhanced in correlation with renal dysfunction: Examination with the redox state of albumin. Kidney Int 66: 1988-1993, 2004

10) Desir GV: Regulation of blood pressure and cardiovascular function by renalase. Kidney Int 76: 366-370, 2009

11) Ito $S$, Nagasawa $T$, Abe M, et al: Strain vessel hypothesis: a viewpoint for linkage of albuminuria and cerebro-cardiovascular risk. Hypertens Res 32: 115-121, 2009

12) Koren-Morag N, Goldbourt U, Tanne D: Renal 
dysfunction and risk of ischemic stroke or TIA in patients with cardiovascular disease. Neurology 67: 224-228, 2006

13) Abramson JL, Jurkovitz CT, Vaccarino V, et al: Chronic kidney disease, anemia, and incident stroke in a middle-aged, community-based population: the ARIC Study. Kidney Int 64: 610615,2003

14) Irie $F$, Iso $H$, Sairenchi $T$, et al: The relationships of proteinuria, serum creatinine, glomerular filtration rate with cardiovascular disease mortality in Japanese general population. Kidney
Int 69, 1264-1271, 2006

15) Ninomiya $T$, Kiyohara $Y$, Kubo M, et al: Chronic kidney disease and cardiovascular disease in a general Japanese population: the Hisayama Study. Kidney Int 68: 228-236, 2005

16）中井 滋, 政金生人, 秋葉 隆ら：わが国の慢性 透析療法の現況 (2006 年 12 月 31 日現在)。透析会 誌 41: 1-28, 2008

17) Toyoda K, Fujii K, Fujimi S, et al: Stroke in patients on maintenance hemodialysis: a 22 -year singlecenter study. Am J Kidney Dis 45: 1058-1066, 2005

\section{Abstract \\ Stroke and chronic kidney disease}

Hiroyuki Terawaki, M.D., Ph.D.' and Masaaki Nakayama, M.D., Ph.D. ${ }^{2)}$

${ }^{1)}$ Division of Kidney and Hypertension, The Jikei University School of Medicine

${ }^{2)}$ Research Division of Dialysis and Chronic Kidney Disease, Tohoku University Graduate School of Medicine

Recently, several cohort studies revealed that predialysis chronic kidney disease (CKD) is closely associated with cardiovascular diseases, as well as stroke. On the other hand, it has been well recognized that CKD under regular dialysis is on the burden of stroke. Here we summarize recent reports regarding the relationship between stroke and CKD.

(Jpn J Stroke 31: 570-574, 2009)

Key words : chronic kidney disease, stroke, cohort study, dialysis, predialysis 